\title{
PERBEDAAN KELANCARAN PENGELUARAN ASI IBU NIFAS SETELAH PERAWATAN PAYUDARA
}

\author{
Atika Asta Octora, Sri Sumiati, Agung Riyadi \\ Politeknik Kesehatan Kementerian Kesehatan Bengkulu, Program Studi D-IV Kebidanan, \\ Jalan Indragiri Nomor 03 Padang Harapan Kota Bengkulu \\ atika_asta@yahoo.com
}

\begin{abstract}
Breast milk (ASI) is the perfect food for infants and contains all the nutrients necessary for the grow than development of infants, issue in this study is the low coverage of exclusive breast feeding for the city of Bengkulu who have not achieved the national target.The purpose of this study was to determine the effect of the Smooth Implementation of Breast Care Spending on Mother Postpartum breast milk in the Work Area Health Center Sukamerindu 2014. This study used a Quasi-Experimental design using Pre-test and Post test design. The independent variabel was the treatment of breast, while the dependent variabel is the smooth expenditure breast milk. The population was all of 1-7 days postpartum mother. It was 30 people. The sampling technique used is total sampling that (15 treatment group and 15 control group). This study starts from 01 January to12 February 2014 in the Work Area Health Center Sukamerindu. From the research results obtained in the treatment group was average of smoothness ASI output prior to treatment was 4.93 and after breast care is 9.33 . In the control group the average of smoothness of spending breastfeeding in the first observation was 4.73 and the second observation is 7.07. Processing data using the $t$ test with $\alpha=0.05$ obtained significant value $\rho=0.000$, it means $\rho<\alpha$ or $\rho=0.000<\alpha=0.05$ means that there is an influence on breast care changes in the smooth of breast milk, from breast milk is not out to be out.
\end{abstract}

Keywords : Breast Care, Smooth of ASI

\begin{abstract}
Abstrak : Air susu ibu (ASI) adalah makanan yang sempurna bagi bayi dan berisi segala nutrisi yang diperlukan untuk pertumbuhan dan perkembangan bayi, masalah pada penelitian ini masih rendahnya cakupan pemberian ASI eksklusif untuk Kota Bengkulu yang belum mencapai target nasional. Tujuan penelitian ini untuk mengetahui Perbedaan Kelancaran Pengeluaran Asi Ibu Nifas Setelah Perawatan Payudara di Wilayah Kerja Puskesmas Sukamerindu tahun 2014. Penelitian ini menggunakan desain Quasi Eksperimen dengan menggunakan Pre-test and Post test design. Variabel independen adalah perawatan payudara sedangkan variabel dependen adalah kelancaran pengeluaran ASI. Populasinya adalah semua ibu nifas 1-7 hari berjumlah 30 orang. Teknik sampling yang digunakan adalah seluruh populasi yaitu (15 orang kelompok perlakuan dan 15 orang kelompok kontrol). penelitian ini di mulai dari tanggal 01 Januari-12 Febuari 2014 di Wilayah Kerja Puskesmas Sukamerindu Dari hasil penelitian yang didapat pada kelompok perlakuan adalah rata-rata kelancaran pengeluaran ASI sebelum dilakukan perawatan payudara 4,93 dan setelah perawatan payudara 9,33. Pada kelompok kontrol rata-rata kelancaran pengeluaran ASI pada observasi pertama adalah 4,73 dan pada observasi kedua 7,07. Pengolahan data menggunakan uji t dengan nilai signifikan $\rho=0,000$, berarti bahwa perawatan payudara ada perbedaan kelancaran pengeluaran ASI ibu nifas setelah perawatan payudara.
\end{abstract}

Kata Kunci : Perawatan Payudara, Kelancaran Pengeluaran ASI

Air susu ibu (ASI) adalah makanan yang sempurna bagi bayi dan berisi segala nutrisi yang diperlukan untuk pertumbuhan dan perkembangan bayi, nutrisi tersebut meliputi protein, karbohidrat, lemak, vitamin, mineral, dan air. Selain itu ASI juga sangat 
bermanfaat bagi bayi, adapun manfaat ASI dapat ditinjau dari berbagai aspek yaitu aspek kecerdasan, aspek gizi, dan aspek imunologi (Ambarwati, 2008).

ASI eksklusif menurut WHO (World Health Organization) adalah pemberian ASI saja tanpa tambahan cairan lain baik susu formula, air putih, air jeruk, ataupun makanan tambahan lain. Di Indonesia Peraturan pemerintah tentang pemberian ASI eksklusif tertuang pada PP Republik Indonesia Nomor 33 tahun 2012 yang mengatakan bahwa untuk mencapai pertumbuhan dan perkembangan yang optimal bayi harus diberi ASI secara eksklusif. ASI memberikan peranan penting dalam menjaga kesehatan dan mempertahankan kelangsungan hidup bayi.Oleh karena itu, bayi yang berumur kurang dari enam bulan dianjurkan hanya diberi ASI tanpa makanan pendamping (Suraji, 2003).

Pada saat ini pemberian ASI eksklusif di Indonesia masih sangat rendah menurut hasil Survei Demografi dan Kesehatan Indonesia (SDKI) tahun 2012 pemberian ASI eksklusif untuk bayi usia 0-1 bulan sebanyak $50,8 \%$, bayi usia 2-3 bulan sebanyak $48,3 \%$ dan 27\% bayi umur 4-5 bulan (SDKI, 2012). Pemberian ASI eks-klusif di Provinsi Bengkulu tahun 2012 sebanyak 41\%. Sedangkan menurut data Dinas Kesehatan Kota Bengkulu berjumlah $51,5 \%$, cakupan ini menurun dibanding tahun 2011 dengan cakupan $56,5 \%$ dari data tersebut pencapaian ASI eksklusif untuk Kota Bengkulu belum mencapai target nasional yaitu $80 \%$.(Profil Kesehatan Kota 2012).

Pada masa nifas agar laktasi berjalan dengan baik dan produksi ASI tercukupi, diperlukan manajemen yang baik dalam laktasi meliputi gizi ibu, psikologi ibu dan perawatan payudara yang benar. Perawatan payudara ini sangat penting dilakukan selama hamil sampai menyusui. Hal ini karena payudara menghasilkan ASI yang merupakan makanan pokok bagi bayi, sehingga perawatan payudara harus dilakukan sedini mungkin karena jika tidak dilakukan perawatan payudara dengan baik maka sering dijumpai kasus-kasus seperti pembengkakan payudara, mastitis, abses payudara sampai ke tumor payudara (Suherni, 2010). Teori ini ditunjang oleh penelitian Innayatulaila, (2011) dan HAsanin (2007) bahwa terdapat pengaruh perawatan payudara terhadap kelancaran ASI.

Perawatan payudara adalah suatu tindakan perawatan payudara yang dilaksanakan baik oleh post partum maupun dibantu oleh orang lain yang dilaksanakan mulai dari hari pertama atau kedua setelah melahirkan. Masalah yang timbul selama masa menyusui dapat dimulai sejak periode antenatal, masa paska persalinan dini (nifas atau laktasi) dan masa paska persalinan lanjut. Salah satu masalah menyusui pada masa paska persalinan dini (masa nifas atau laktasi) adalah puting susu nyeri, puting susu lecet, payudara bengkak, dan mastitis. Timbulnya masalah tersebut diakibatkan oleh pengeluaran ASI yang tidak lancar, dan banyak ibu yang belum mengetahui tentang teknik perawatan payudara sehingga untuk pemberian ASI eksklusif kurang efisien (Ambarwati, 2008).

Vivian dkk (2011), juga mengemukakan hambatan dalam menyusui dipengaruhi oleh beberapa faktor diantaranya faktor ibu, bayi dan lingkungan. Faktor ibu yaitu kurangnya informasi, puting susu terbenam atau datar, puting lecet, payudara bengkak, abses payudara, sindrom ASI kurang. Faktor bayi yaitu bayi bingung puting, bayi sering menangis, bayi dengan labioskisis dan labioplatokisis, sedangkan faktor lingkungan diantaranya ibu berkerja, maraknya peredaran susu formula yang dianggap praktis yang dapat menggantikan ASI.

Di dalam masyarakat sering kita jumpai khususnya ibu-ibu yang cenderung menolak menyusui bayinya sendiri terutama pada ibu-ibu yang bekerja dengan alasan air susunya hanya sedikit atau tidak keluar sama sekali, keadaan ini memberikan dampak negatif terhadap status kesehatan, gizi, serta tingkat kecerdasan anak. Terjadinya penyulit pada saat dilakukan proses laktasi tentunya akan sangat merugikan ibu maupun bayi. Timbulnya penyulit tersebut diakibatkan oleh beberapa hal, dan yang paling sering muncul adalah pengeluaran ASI yang tidak lancar. 
Dari hasil wawancara pada petugas gizi yang bertanggung jawab sebagai petugas ruang laktasi didapatkan faktor ibu tidak memberikan ASI eksklusif di Puskesmas Sukamerindu antara lain ibu berkerja, puting susu datar, payudara bengkak, lecet dan sebagaian besar mengalami ketidak lancaran ASI, hal ini merupakan salah satu faktor rendahnya cakupan pemberian ASI eksklusif di Puskesmas Sukamerindu dengan Cakupan 47,5\% di bawah target pemberian ASI eksklusif untuk Kota Bengkulu sebesar 51,5 \%, oleh karena itu harus dilakukan perawatan payudara yang baik dan benar pada ibu post partum.

Melakukan perawatan payudara secara teratur dan benar maka proses menyusui akan menjadi lebih lancar. Kondisi ini tentunya akan menguntungkan bagi bayi dan ibu karena kebutuhan nutrisi bayi akan terpenuhi dan terjadinya kelainan-kelainan pada payudara ibu dapat dihindari, untuk menanggulangi permasalahan di atas perlu dilakukan upaya preventif dan promotif dalam meningkatkan penggunaan ASI secara eksklusif dengan memberikan pendidikan kesehatan tentang perawatan payudara pada saat menyusui, sehingga membantu pengeluaran ASI secara lancar (Prasetyono, 2009).

Untuk menunjang kenaikan pemberian ASI eksklusif di Kota Bengkulu berdasarkan data survei awal didapatkan 12 tempat yang memiliki ruang laktasi yaitu Puskesmas Ratu Agung, Puskesmas Beringin Raya, Puskesmas Sukamerindu, Dinas Kesehatan Provinsi, Dinas Kesehatan Kota, Rumah Sakit Daerah Dr. M. Yunus, Pemda Kota, Biro Pemberdayaan Perempuan Pemda Provinsi, Badan Pemberdayaan Masyarakat Perempuan dan Keluarga Berencana, Kantor Kecamatan Gading, Kantor Kecamatan Ratu Agung, dan Bandara. Ruang Laktasi yang masih aktif yaitu terdapat di Puskesmas Beringin Raya, Puskesmas Sukamerindu dan Pemda Kota tetapi hanya Puskesmas Sukamerindu yang ruang Laktasinya berjalan dengan baik. Dari hasil survei awal yang dilakukan di Puskesmas Sukamerindu dari 10 orang ibu nifas yang ditanya 7 orang ibu nifas merawat payudara dengan baik dan pengeluaran ASI lancar, 3 orang ibu nifas tidak merawat payudara, 1 orang ibu nifas ASI lancar dan 2 orang ibu nifas ASI tidak lancar.

Berdasarkan hal di atas penulis tertarik untuk melakukan penelitian tentang "Pengaruh Perawatan Payudara terhadap Kelancaran Pengeluaran ASI pada Ibu Nifas di Wilayah Kerja Puskesmas Sukamerindu tahun 2014”.

\section{BAHAN DAN CARA KERJA}

Penelitian ini menggunakan metode Quasi Eksperimen dengan menggunakan rancangan sebelum dan sesudah intervensi menggunakan dua kelompok. Desain penelitian ini menggunakan Pre-test and Post test desaign. Dalam desain ini unit eksperimen tersebut berfungsi sebagai kelompok eksperimen dan kelompok kontrol. Variabel dalam penelitian ini terdiri dari variabel bebas (Penatalaksanaan perawatan payudara) dan Variabel terikat (Kelancaran ASI) (Notoatmodjo, 2005).

Populasi dalam penelitian ini seluruh ibu nifas 1-7 hari di Wilayah Kerja Puskesmas Sukamerindu Kota Bengkulu berjumlah 30 orang. Pengambilan sampel dalam penelitian ini menggunakan teknik total sampling yaitu semua ibu nifas 1-7, kemudian sampel dibagi menjadi dua kelompok, menggunakan teknik random yaitu 15 orang kelompok eksperimen dan 15 orang kelompok kontrol. Kelompok eksperimen dilakukan perlakuan atau perawatan payudara selama 4 hari. Untuk menentukan layak atau tidaknya sampel mewakili keseluruhan populasi, maka dibuatlah kriteria inklusi yaitu: bersedia menjadi responden dan semua ibu nifas 1-7 hari. Penelitian ini dilaksanakan di Wilayah Kerja Puskesmas Sukamerindu Kota Bengkulu dari tanggal 03 Januari-12 Febuari 2014. Variable kelancaran ASI dinilai dengan cara banyaknya ASI yang keluar sesuai dengan kebutuhan bayi ditandai setelh menyusu bayi kenyang.

Analisa data dilakukan secara bertahap yaitu analisa univariat bertujuan untuk memperoleh gambaran masing-masing variabel baik variabel dependen maupun variabel independen. Sedangkan analisa bivariat dila- 
kukan untuk menguji hipotesis antara variabel independen dan variabel dependen untuk melihat pengaruh antara variabel independen dan variabel dependen dengan uji kemaknaan secara statistik menggunakan uji $\mathrm{T}$ pada tingkat kepercayaan $95 \%$ dan probabilitas pada taraf 5\% untuk mengetahui pengaruh pelaksanaan perawatan payudara terhadap kelancaran pengeluaran ASI pada ibu nifas di wilayah Kerja Puskesmas Sukamerindu Kota Bengkulu Tahun 2014.

\section{HASIL}

\section{Analisis Univariat}

Tabel 1. Rata-Rata Kelancaran Pengeluaran ASI

\begin{tabular}{|c|c|c|c|c|c|c|}
\hline Variabel & $\mathrm{F}$ & $\%$ & Mean & SD & Max & Min \\
\hline \multicolumn{7}{|c|}{ Kelompok Perlakuan } \\
\hline Observasi & 1 & 6,7 & 4,93 & 0,961 & 3 & 6 \\
\hline \multirow[t]{3}{*}{ pertama } & 4 & 26,7 & & & & \\
\hline & 5 & 33,3 & & & & \\
\hline & 5 & 33.3 & & & & \\
\hline Observasi & 2 & 13,3 & 9,33 & 1,291 & 7 & 11 \\
\hline \multirow[t]{4}{*}{ kedua } & 1 & 6,7 & & & & \\
\hline & 5 & 33,3 & & & & \\
\hline & 4 & 26,7 & & & & \\
\hline & 3 & 20,0 & & & & \\
\hline \multicolumn{7}{|c|}{ Kelompok Perlakuan } \\
\hline Observasi & 1 & 6,7 & 4,73 & 0,961 & 3 & 5 \\
\hline \multirow[t]{3}{*}{ Pertama } & 6 & 4,0 & & & & \\
\hline & 4 & 26,7 & & & & \\
\hline & 4 & 26,7 & & & & \\
\hline Observasi & 2 & 13,3 & 7,07 & 1,534 & 6 & 10 \\
\hline \multirow[t]{4}{*}{ kedua } & 4 & 26,7 & & & & \\
\hline & 5 & 33,3 & & & & \\
\hline & 3 & 20,0 & & & & \\
\hline & 1 & 6,7 & & & & \\
\hline
\end{tabular}

Berdasarkan tabel 1 dapat dilihat bahwa dari 15 responden pada kelompok perlakuan terdapat seluruh (100\%) responden tidak mengalami kelancaran pengeluaran ASI sebelum dilakukan perawatan payudara dan setelah dilakukan perawatan payudara sebagian besar $(86,7 \%)$ responden mengalami kelancaran pengeluaran ASI.

Pada kelompok kontrol seluruh $(100 \%)$ responden tidak mengalami kelancaran pengeluaran ASI pada observasi pertama dan pada observasi kedua sebagian sebagian besar $(73,3 \%)$ responden tetap tidak mengalami pengeluaran ASI. Selain itu dapat dilihat juga hanya sebagian kecil $(26,7 \%)$ responden mengalami kelancaran pengeluaran ASI.

\section{Analisis Bivariat}

Berdasarkan tabel 2 dapat dilihat bahwa rata-rata kelancaran pengeluaran ASI pada kelompok perlakuan sebelum perawatan payudara adalah 4,93 dan setelah diberikan perawatan payudara adalah 9,33. Hasil uji statistik didapatkan nilai $\mathrm{p}=0,000$ sehingga dapat disimpulkan ada perbedaan yang signifikan antara kelancaran pengeluaran ASI sebelum dilakukan perawatan payudara dan sesudah perawatan payudara. Sedangkan rata-rata kelancaran pengeluaran ASI untuk kelompok kontrol pada observasi pertama adalah 4,73 dan pada observasi kedua 7,07. Hasil uji statistik didapatkan nilai $\mathrm{p}=0,000$, disimpulkan ada perbedaan yang signifikan antara kelancaran pengeluaran ASI pada observasi pertama dan observasi kedua.

Tabel 2. Rata-rata Kelancaran Pengeluaran ASI

\begin{tabular}{ccccc}
\hline Variabel & n & Rata-rata & SD & $\begin{array}{c}\text { Nilai p } \\
\text { Value }\end{array}$ \\
\hline $\begin{array}{c}\text { Kelompok Perlakuan } \\
\text { Observasi pertama }\end{array}$ & 1 & 4,93 & 0,961 & 0,000 \\
Observasi Kedua & 5 & 9,33 & 1,291 & \\
Kelompok Kontrol & & & & \\
Observasi pertama & 1 & 4,73 & 0,961 & 0,000 \\
Observasi Kedua & 5 & 7,07 & 1,534 & \\
\hline
\end{tabular}

Tabel 3 Perbedaan Peningkatan Rata-Rata Kelancaran ASI untuk Kelompok Perlakuan dan Kelompok Kontrol

\begin{tabular}{|c|c|c|c|c|}
\hline Variabel & $\mathbf{n}$ & Rata-rata & $S D$ & $\begin{array}{l}\text { Nilaip } \\
\text { Value }\end{array}$ \\
\hline $\begin{array}{l}\text { Kelancaran } \\
\text { pengeluaran ASI } \\
\text { pada kelompok } \\
\text { perlakuan }\end{array}$ & 15 & 4,47 & 1,187 & 0,000 \\
\hline $\begin{array}{l}\text { Kelancaran } \\
\text { pengeluaran ASI } \\
\text { pada kelompok } \\
\text { kontrol }\end{array}$ & 15 & 2,33 & 0,976 & \\
\hline
\end{tabular}

Tabel 3 dapat dilihat bahwa peningkatan rata-rata kelancaran pengeluaran ASI setelah dilakukan perawatan payudara pada kelompok perlakuan adalah 4,47 sedangkan 
untuk kelompok kontrol peningkatan kelancaran pengeluaran ASI pada observasi dua adalah 2,33 dengan uji statistik $t$ independen didapatkan nilai $\mathrm{p}=0,000$ berarti ada perbedaan yang signifikan antara peningkatan kelancaran pengeluaran ASI pada kelompok perlakuan dan kelompok control.

\section{PEMBAHASAN}

Berdasarkan hasil analisis univariat terhadap data perubahan kelancaran pengeluaran ASI yang dialami ibu nifas di Wilayah Kerja Puskesmas Sukamerindu Kota Bengkulu diketahui bahwa pada kelompok perlakuan hampir seluruhnya mengalami kelancaran pengeluaran ASI setelah dilakukan perawatan payudara, sebagian kecil responden yang tidak mengalami kelancaran pengeluaran ASI pada kelompok perlakuan dapat disebabkan karena ibu mengeluh bayinya tak mau menyusu dan ibu stres mengurusi bayinya.

Hal ini sesuai dengan pendapat Ambarwati (2008), faktor-faktor yang memengaruhi kelancaran pengeluaran ASI antara lain melakukan perawatan payudara dengan benar, nutrisi ibu saat menyusui, kondisi psikis, faktor istirahat dan faktor isapan anak. Menurut Saryono (2008), gerakan pada perawatan payudara bermanfaat melancarkan reflek pengeluaran ASI.

Hal ini didukung juga dengan pendapat Suherni (2008) menyatakan faktor yang memengaruhi keberhasilan ibu menyusui dengan pengeluaran ASI lancar yaitu faktor psikis, jika memang sejak awal diniatkan dan diyakini untuk memberikan ASI, pastilah susu juga akan keluar. Makin kurang persiapan, tekanan pada pikiran, atau ketidakmauan karena berbagai alasan, akan menghambat keluarnya ASI. Tetapi, pada umumnya, masalah tidak keluar atau terhambatnya ASI karena dua hal yaitu ASI kepenuhan dan saluran susu tersumbat.

Hasil penelitian ini sesuai dengan penelitian yang dilakukan Innayatulaila (2011), menyatakan dari 7 sampel terdapat 6 responden yang mengalami kelancaran pengeluaran ASI setelah melakukan perawatan payudara. seluruh responden pada kelompok kontrol tidak mengalami kelancaran pengeluaran ASI pada observasi pertama hal ini disebabkan karena pada hari pertama ASI belum keluar. Hal ini juga didukung oleh Vivian (2011), yang berpendapat bahwa pada hari pertama ASI yang keluar hanya kolostrum sampai hari ke-4 tetapi kita harus menganjurkan ibu nifas untuk menyusui sesering mungkin agar merangsang ASI untuk keluar. Sebagian besar responden tetap tidak mengalami kelancaran pengeluaran ASI dan sebagian kecil responden mengalami kelancaran pengeluaran ASI pada observasi kedua. Tidak terjadinya perubahan kelancaran pengeluaran ASI pada sebagian besar responden untuk kelompok kontrol dapat disebabkan karena tidak adanya perlakuan yang diberikan dalam upaya meningkatkan kelancaran pengeluaran ASI dan ibu mengalami gangguan psikologi.

Saifuddin (2006) menyatakan bahwa karakteristik responden mayoritas mengalami resiko gangguan pengeluaran ASI terjadi karena timbul gangguan psikologi seperti perasaan ketidakmampuan untuk merawat bayi dan dirinya sendiri, dan terjadi penolakan menyusui bayinya sehingga payudara tidak dikosongkan dengan baik, maka pesan hormonal yang diterima otak ibu adalah untuk menghasilkan air susu lebih sedikit. Pengeluaran ASI merupakan suatu interaksi yang sangat komplek antara rangsangan mekanik, saraf dan bermacam-macam hormon.

Hasil analisis bivariat menunjukan ada perbedaan yang signifikan antara peningkatan kelancaran pengeluaran ASI pada kelompok perlakuan dan kelompok kontrol sehingga dapat disimpulkan bahwa perawatan payudara mempunyai pengaruh terhadap kelancaran pengeluaran ASI pada ibu nifas di Wilayah Kerja Puskesmas Sukamerindu Kota Bengkulu tahun 2013.

Hasil penelitian ini sesuai dengan pendapat Anik (2009), yang menyatakan bahwa perawatan payudaraakan menaikan atau melancarkan pengeluaran ASI dari payudara yang dipengaruhi oleh adanya bahan metabolisme yang membantu terjadinya produksi 
ASI di dalam glandula mamae sehingga dapat memperlancar aliran dari duktus laktiferus, sinus luktiferus dan kelenjar-kelenjar dari pembentukan kolostrum awal dan menyebabkan lancarnya aliran-aliran sinus. Selain itu dilakukannya perawatan payudara akan dapat memperlancar sirkulasi pembuluh darah vena dan limfe pada sistem limfe sehingga merangsang kelancaran pengeluaran ASI pada duktus laktiferus.

Hasil penelitian ini sama dengan penelitian Ruslan Hasani (2007) bahwa ada perbedaan yang signifikan antara kelompok perlakuan dan kelompok kontrol. Hal ini disebabkan karena pemijatan payudara meningkatkan laju air susu, lancarnya aliran pada sirkulasi atau pembuluh darah maka secara otomatis akan lebih melancarkan aliran oksitosin pada pembuluh darah yang akan melancarkan pengeluaran ASI dan penurunan ASI pada aerola yang kemudian akan keluar bersamaan dengan hisapan bayi.

\section{KESIMPULAN}

Dari hasil penelitian yang didapat pada kelompok perlakuan adalah rata-rata kelancaran

\section{DAFTAR RUJUKAN}

Ambarwati dan Wulandari. 2008. Asuhan Kebidanan Nifas. Yogyakarta: Mitra Cendekia Press.

Anik M, 2009. Asuhan Kebidanan pada Masa Nifas (Post Partum). Jakarta : Trans Info Media

Arianto, 2004.Anatomi Payudara dan Fisiologi Laktasi. Ahad, 6 September 2009; pukul 10:55 WIB

http://sobatbaru.blogspot.com/2009/02/anatomi payudara-dan-fisiologi laktasi.html

Dinas Kesehatan Kota, 2012. Profil Kesehatan Kota Bengkulu Tahun 2012.Bengkulu: Dinkes Kota Bengkulu

Dinas Kesehatan Provinsi ,2012. Profil Kesehatan Kota Bengkulu Tahun 2012. Bengkulu: Dinkes Provinsi Bengkulu

Hanum, 2010.Tumbuh Kembang Status Gizi dan Imunisasi Dasar pada Balita. Yogyakarta: Nuha Medika

Huliana, M. 2003. Perawatan Ibu Paska Melahirkan. Jakarta: Puspa Swara pengeluaran ASI sebelum dilakukan perawatan payudara 4,93 dan setelah perawatan payudara 9,33. Pada kelompok kontrol rata-rata kelancaran pengeluaran ASI pada observasi pertama adalah 4,73 dan pada observasi kedua 7,07. Ada perbedaan kelancaran pengeluaran ASI ibu nifas setelah perawatan payudara

Bagi petugas kesehatan khususnya bidan agar lebih meningkatkan keterampilan melalui literatur terbaru, pelatihan, konseling pada setiap pemeriksaan kehamilan, serta kunjungan rumah dan pembagian leaflet perawatan payudara sehingga dapat meningkatkan kesadaran dan kemauan ibu nifas untuk melakukan perawatan payudara dalam proses persiapan laktasi pada ibu nifas.

Dalam penelitian ini peneliti hanya melakukan pre-test 1 hari di harapkan penelitian selanjutnya melakukan pre-test lebih dari 1 hari sehingga dapat dilihat secara benar perbedaan kelancaran pengeluaran ASI setelah dilakukan perawatan payudara dan bukan hanya penatalaksanaan perawatan payudara yang memengaruhi kelancaran pengeluaran ASI.

Notoatmodjo, Soekidjo. 2002. Metodologi Penelitian Kesehatan. Jakarta: Rineka Cipta.

Prasetyono, Dwi Sunar. 2009. Buku Pintar ASI eksklusif pengenalan, praktik, dan pemanfaatannya. Jogjakarta: Diva Press.

Saryono dan Pramitasari.2008. Perawatan Payudara Dilengkapi dengan Deteksi Dini Terhadap Penyakit Payudara. Yogyakarta: Mitra Cendekia Press.

Suherni ,2010 . Perawatan Payudara pada Masa Kehamilan dan Masa Nifas, Yogyakarta: Fitramaya

Sulisyawati, A. 2009. Buku Ajar Asuhan Kebidanan Ibu Nifas. Jakarta: Salemba Medika

Suradi, Ruliana Prof. Dr. 2008. Manajemen Laktasi. Jakarta: Perkumpulan Perinatologi Indonesia.

Vivian, 2011. Asuhan Kebidanan pada Masa Nifas. Jakarta: Salemba Medika.

Weni, 2011. Asuhan Kebidanan Masa Nifas. Yogyakarta: Pustaka Rihana. 